\title{
ANALISIS PERMASALAHAN KOPERASI BAITUL MAAL WA TAMWIL (KBMT) PERKOTAAN (Studi Kasus KBMT di Kota Bogor)
}

\author{
Ahmad Khoirudin \\ Nashr Akbar \\ Program Studi Ilmu Ekonomi Islam \\ Sekolah Tinggi Ekonomi Islam Tazkia Bogor
}

\begin{abstract}
Microfinance as an effective tool provides financial service for those who do not have the access or could not be accessed by a commercial bank or other financial institution. The Growth of Baitul Maal wa tamwil (BMT) as one of the Islamic financial institution is very fast and massive. There are many challenges and obstacles that inhibit the growth of it, either from internal or external of BMT. The purpose of this study is to identify the issues faced by the urban of BMT (Bogor City), used Analytic Network Process (ANP). The study also attempt to provide solution of the BMT problem faced. The result of this study showed that the problem of internal Issues was more dominant than External Issues, with the priority level of 54\%. Based on the Internal Problems aspect, the dominant issue was the problem of "Low Quality and understanding of Human Resource". Meanwhile an aspect of the external problem is "the strictness of Business Competition". Furthermore, the solution could be implemented are 1) Training for Human Recourse 2) BMT Mentoring by the relevant government.
\end{abstract}

Keywords: Microfinance, BMT, and Analytic Network Process (ANP)

Usaha Mikro Kecil dan Menengah (UMKM) adalah institusi yang dapat bertahan terhadap krisis yang terjadi di beberapa negara. Krisis keuangan tahun 1997 dan 1998 yang melanda Indonesia menunjukkan bahwa unit usaha ini menjadi jalan keluar yang dapat mempertahankan kestabilan perekonomian negara. Dikarenakan pentingnya UMKM maka pemerintah juga harus mempersiapkan bagaimana mengembangkan UMKM tersebut. salah satunya adalah dengan memberi dukungan kepada Lembaga Keuangan Mikro, agar dapat menyalurkan dana kepada masyarakat.

Pertumbuhan UMKM di Indonesia begitu pesat, selama tahun 2012 jumlah UMKM sebanyak 1.328.147 (Depkop). Namun kondisi tersebut berbeda pada tahun 2010, dimana dari hasil survei rumah tangga yang dilakukan Bank Indonesia menunjukkan bahwa $62 \%$ rumah tangga tidak memiliki tabungan sama sekali. Jumlah kepemilikan rekening tabungan masih di bawah 50\% dari total penduduk Indonesia. Saat ini yang hanya sekitar 19,6\% masyarakat Indonesia berusia di atas 15 tahun yang mempunyai rekening tabungan. (Wibowo, 2013)

Gambaran jumlah penabung di atas dapat menjadi representasi dari jumlah pengguna jasa layanan bank, baik dalam segi tabungan, pembiayaan dan jasa lainnya. Sehingga hal ini menunjukkan bahwa masih banyak masyarakat yang tidak tersentuh dengan pelayanan perbankan, dan sudah selayaknya mereka mendapat perhatian lebih dari pemerintah.

Hadirnya Lembaga keuangan Mikro (LKM) menjadi jalan keluar yang tepat untuk mencukupi kebutuhan dana bagi UMKM atau mereka yang tidak tersentuh oleh pelayanan bank (unbanked). Hal ini dikarenakan LKM adalah lembaga yang dapat menyentuh hingga ke level terendah dari masyarakat. Oleh karena itu LKM adalah sarana yang tepat untuk menjawab permasalahan diatas, diantaranya mengurangi jumlah kemiskinan dan membantu UMKM dalam mempertahankan perekonomian negara.

LKM memiliki dua bentuk yaitu: LKM yang berlandaskan Islam dalam pengoprasiannya dan LKM yang tidak melandaskan Islam dalam proses operasinya (konvensional). Ditinjau dari pembagian wilayah Kementrian Koperasi dan UMKM, dibedakan menjadi dua: LKM (koperasi) perkotaan dan pedesaan.

Terdapat beberapa Lembaga Keuangan Mikro Islam di Indonesia, salah satunya adalah Baitul Maal Wa Tamwil (BMT). Riwajanti (2014) juga mengatakan bahwa BMT memiliki karakter yang unik, yang 
tidak dimiliki oleh LKM secara umum: diantaranya 1) BMT adalah organisasi yang didasari oleh komunitas yang memiliki badan hukum koperasi. 2) Memberikan pelayanan keuangan bagi masyarakat bawah (low level) yang lebih fleksibel dan cepat dibandingkan dengan Bank Umum. 3) BMT juga mencoba menanamkan nilai islam dalam setiap aktifitasnya, termasuk dalam produk pembiayaannya. Dan hal ini menjadi kelebihan BMT dibandingkan dengan LKM secara umum.

BMT adalah lembaga yang memiliki badan hukum yang sama dengan koperasi, maka pembagian wilayah juga terjadi pada BMT. Hal ini bertujuan untuk memudahkan dalam mengidentifikasi kebutuhan dan karakter dari lembaga tersebut. Pembagian ini juga berfungsi dalam penyebaran lembaga secara menyeluruh, tidak hanya di perkotaan namun juga pedesaan. Selain itu menurut (Susanto: 2015 dan Arkham: 2015) pembagian wilayah juga digunakan untuk mengidentifikasi pendekatan keuangan mikro apa yang dapat digunakan untuk masing- masing daerah. Selanjutnya, dengan adanya BMT ini maka akan dapat menjadi sebuah opsi untuk mencapai pembangunan ekonomi. Dimana tujuan pembangunan ekonomi secara umum adalah memberikan kepuasan kepada setiap individu masyarakat dalam hal ini kecukupan dalam ekonomi. Dan bukan hanya pembangunan ekonomi saja yang dapat dicapai dengan hadirnya BMT, namun juga pembangunan negara yang meliputi pembangunan dalam hal pendidikan, kesehatan dan spiritual. Sehingga tercapai pembangunan yang berkelanjutan (World Bank, 2013).

Pembangunan yang berkelanjutan itu, tidak akan tercapai dengan hanya memberikan dana atau pembiayaan saja. Namun untuk mencapainya, masyarakat membutuhkan pendidikan dan bantuan untuk pengembangan usaha mereka. Dua hal tersebut dimiliki oleh LKM Islam (BMT). Diantaranya fungsi mediasi, sebagai lembaga penyedia dana dan pembiayaan serta fungsi pemberdayaan yang juga dilakukan oleh BMT. Kedua fungsi diatas dapat membantu pencapaian dari tujuan pembangunan tersebut.

Peluang bagi LKM Syariah begitu besar dalam pemberian kredit usaha ataupun yang lainnya kepada masyarakat. Hal ini yang menunjukkan bahwa LKM sangat dibutuhkan. Selain itu adanya LKM Syariah (BMT) menjadi pilihan baru bagi masyarakat yang rindu akan pelaksanaan nilai islam dalam kegiatan perekonomian. Melihat perkembangan BMT dalam hal ini dari perkembangan aset dari PBMT ventura sebagai perhimpunan BMT di Indenesia, dari tahun 2007 hingga 2012 mengalami peningkatan yang signifikan. Pada tahun 2007 total aset PBMT Ventura adalah Rp. 8,19 Miliar hingga mencapai 139,09 Miliar pada tahun 2012.

Peningkatan ini menunjukkan bahwa semakin banyak peserta yang tergabung dalam perhimpunan ini. Dengan jumlah anggota pada tahun 2010 sejumlah 562 unit BMT. Hal ini menjadi representasi dari pertumbuhan BMT di Indonesia yang semakin hari semakin meningkat. Dari data tersebut pula bisa disimpulkan bahwa kebutuhan masyarakat atas BMT sendiri begitu besar.

Namun berbeda halnya yang terjadi di Kota Bogor. Menurut Arkham (2015), di Bogor sendiri jumlah BMT menurun. Dilihat dengan keputusan beberapa BMT yang mengundurkan diri dari Kota Bogor atau bahkan sudah non-aktif. Data dari dinas koperasi dan UMKM tercatat 750 unit koperasi dan hanya 353 yang masih aktif. Dan khususnya BMT terdapat 13 BMT di Kota Bogor. 9 dari 13 BMT

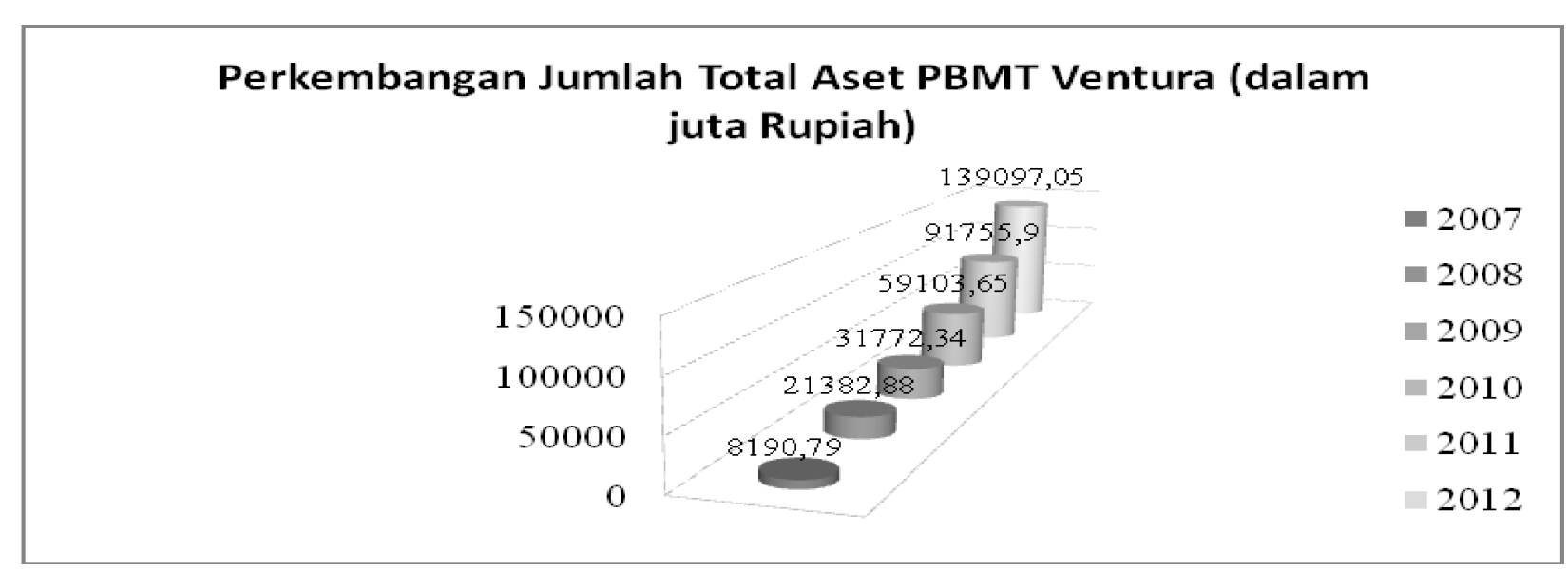

Gambar 1. Total Aset PBMT Ventura

Sumber: PBMT Ventura 
tersebut sudah tidak beroperasi lagi. Hal ini menjadi seperti anomali, disaat data pusat mengalami peningkatan namun di Kota Bogor mengalami penurunan.

Aam dan Devi (2012), menyebutkan bahwa terdapat beberapa masalah yang dihadapi BMT di Indonesia. 1) Masalah SDM, dimana kurangnya pemahaman praktisi baik dalam pengembanga BMT maupun dalam sisi syariahnya, 2) Masalah teknis berkaitan dengan penyediaan data terbaru dan dana pengembangan BMT yang relatif kecil, 3) Masalah Legal/struktural, berkaitan dengan legal formal dan 4) Masalah Komunal/pasar, persaingan yang padat baik dari antar BMT maupun dengan tumbuh pesatnya warung- warung mikro yang di buat oleh bank- bank umum. Sehingga masih banyak yang harus dibenahi bersama.

Hasil penelitian terdahulu diringkas sebagai berikut: Hamzah, dkk (2013) menjelaskan permasalah yang terjadi pada BMT di Pekanbaru dan solusinya. Yaron dan Benjamin (1997), mencontohkan BRI Unit desa telah sukses dalam menyediakan pelayanan keuangan bagi pedesaan. Riwajanti (2014), menerangkan bahwa berdasarkan Head Count Index dan garis kemiskinan yang ditetapkan oleh BPS pada tahun 2012, temuan penting menunjukkan bahwa pembiayaan berkontribusi dalam mengurangi persentase penduduk miskin. Ascarya dkk (2007), menjelaskan terdapat 44 juta UMKM di Indonesia yang menopang $99.9 \%$ bisnis. Dan ironinya hanya $22.14 \%$ saja yang mendapatkan fasilitas keuangan. Rahim (2010) menjelaskan bahwa Islam berpotensi dalam memberikan skema atau instrumen yang dapat digunakan dalam upaya membantu pencapaian tujuan dari microfinance. Ahmed (2009) menjelaskan bahwa kredit mikro yang berasal dari Bangladesh telah menyebar secara global. Dan prestasi yang dicapai oleh bangladesh juga baik. Afriadi (2012) menjelaskan bahwa berdasarkan penelitian yang dilakukannya permasalahan BMT dibagi menjadi dua aspek utama, internal dan eksternal. Susanti (2012) menjelaskan bahwa kendala yang ada dibagi menjadi dua. Kendala internal dan eksternal adalah kendala utama.

Dengan melihat latar belakang inilah, maka penelitian ini ingin menganalisis permasalahan BMT Perkotaan (studi kasus BMT di Kota Bogor).

\section{METODE}

Data yang digunakan dalam penelitian ini adalah data primer dan sekunder. Peneliti mendapatkan data sekunder yang berasal dari Dinas Koperasi dan UMKM, yaitu Statistik Perkembangan Koperasi di Kota Bogor. Data primer diperoleh melalui: (1) Indepth Interview, yaitu wawancara secara mendalam untuk menjaring informasi yang detail mengenai objek permasalahan yang dibahas dalam penelitian ini. (2) Survey Pakar dan Praktisi, yaitu pengumpulan data yang dititik beratkan bagi kalangan ekonom syariah dan para praktisi Lembaga Keuangan Mikro Syariah.

Responden dalam penelitian ini dibedakan menjadi dua kategori, yaitu kategori pakar dan praktisi. Pakar adalah para ahli ekonomi syariah dan akademisi di bidang Ekonomi Islam. Praktisi adalah para ahli bidang keuangan Syariah baik itu dalam bidang LKMS maupun dalam bidang non LKMS, selain itu juga orang yang secara langsung terjun ke dalam praktek kegiatan Keuangan Mikro Syariah yang paham betul akan masalah yang diangkat.

Data dan informasi mengenai pendapat yang diwakili oleh para pakar dan praktisi disusun dalam bentuk model kerangka. Jika hasil kuesioner tentang tanggapan, atau pendapat telah terkumpul, maka langkah selanjutnya adalah analisis hasil yang diperoleh, dengan menggunakan software "Super Decision".

Penelitian ini menggunakan metode kuantitatifkualitatif di mana penelitian ini bertujuan untuk mengetahui apa permasalahan yang dialami BMT Perkotaan khususnya Kota Bogor. Untuk mencapai tujuan tersebut, maka penelitian ini akan mencari tahu pendapat para pakar dan praktisi dibidang BMT, dengan pendekatan kualitatif. Sedangkan pendekatan kuantitatif digunakan saat pengolahan data melalui Super Decision untuk mengetahui skala prioritas dari hasil pendekatan kualitatif yang telah dilakukan sebelumnya.

\section{Gambaran Umum Metode Analytic Network Process (ANP)}

Menurut Saaty (2003, dalam Ascarya 2005) ANP adalah teori umum pengukuran relatif yang digunakan untuk menurunkan rasio prioritas komposit dari skala rasio individu yang mencerminkan pengukuran relatif dari pengaruh elemen-elemen yang saling berinteraksi berkenaan dengan kriteria kontrol. Metode ini dikembangkan pertama kali oleh Thomas L Saaty, yang merupakan perkembangan dari metode Analytic Hierarchy Process (AHP). ANP merupakan pendekatan baru dalam proses pengambilan keputusan tanpa membuat asumsi. 
Ascarya menjelaskan (2005) bahwa ANP memiliki beberapa kelebihan, yaitu kemampuannya untuk membantu peneliti dalam melakukan pengukuran sintesis sejumlah faktor-faktor dalam jaringan. Kemudian kesederhanaan konsep membuat ANP menjadi metodologi yang lebih umum dan lebih mudah diaplikasikan untuk studi kualitatif yang beragam seperti pengambilan keputusan, forecasting, evaluasi, mapping, strategizing, alokasi sumber daya dan lain sebagainya. Selain itu komparasi dalam kerangka ANP lebih objektif, prediksi yang lebih akurat, dan hasil yang lebih stabil.

ANP digunakan untuk pemecahan masalah yang bergantung pada alternatif dan kriteria yang ada. Menurut Saaty dan Vargas (2006) dalam teknis analisisnya, ANP menggunakan perbandingan berpasangan pada alternatif dan kriteria proyek. Pada jaringan AHP terdapat level tujuan, kriteria, sub-kriteria, dan alternatif, di mana masing-masing level memiliki elemen. Sementara itu, pada jaringan ANP, level dalam AHP disebut cluster yang dapat memiliki kriteria dan alternatif di dalamnya, yang disebut simpul. Saaty dan Vargas (2006) menyebut hubungan langsung dari simpul ke cluster dengan nama outer dependence. Sementara itu, terdapat simpul utama dan simpul yang akan dibandingkan berada pada cluster yang sama, sehingga cluster ini terhubung dengan dirinya sendiri dan membentuk hubungan. Hal ini disebut inner dependence.

Metode ANP ini digunakan untuk mengetahui keseluruhan pengaruh dari semua kriteria dan alternatif. Oleh karena itu, semua kriteria harus diatur dan dibuat prioritas dalam suatu kerangka kerja jaringan, melakukan perbandingan dan sintesis untuk memperoleh urutan prioritas dari sekumpulan kriteria ini. Kemudian kita turunkan pengaruh dari elemen dalam sistem feedback dengan memperhatikan masingmasing kriteria. Akhirnya, hasil dari pengaruh ini dibobot dengan tingkat kepentingan dari kriteria, dan ditambahkan untuk memperoleh pengaruh keseluruhan dari masing-masing elemen (Saaty dan Vargas, 2006).

\section{Tahapan Penelitian}

Penelitian ini terdiri dari empat tahapan penelitian, tahapan pra penelitian, pengumpulan data, pengolahan data dan interpretasi hasil. Tahapan pertama dimulai dari pengidentifikasian, menentukan ide-ide atau gagasan dan penentuan objek penelitian, dan hasil langkah ini berupa topik penelitian. Langkah selanjutnya dalam tahapan ini adalah perumusan masalah dan penentuan tujuan penelitian dan kemudian dilanjutkan dengan membuat rancangan pengumpulan data.

Tahap kedua dalam penelitian ini yaitu dengan melakukan studi lapangan ke tempat penelitian yang bertujuan untuk memastikan ketersediaan data-data yang dibutuhkan dalam melakukan penelitian. Data yang digunakan berupa data primer dan data sekunder. Data primer merupakan data yang diperoleh dari sumber pertama melalui wawancara dan kuesioner. Sedangkan data sekunder diperoleh dari bahan pustaka maupun instansi terkait yang berhubungan dengan penelitian, seperti Dias Koperasi dan UMKM Kota Bogor dan Badan Pusat Statistik.

\section{PEMBAHASAN DAN HASIL}

\section{Identifikasi Permasalahan dan Solusi}

\section{Cluster Masalah dan Solusi}

Isi dari cluster ini terdiri dari permasalahanatau kendala yang menghambat perkembangan BMT sehingga menyebabkan matinya beberapa BMT di kota Bogor. (i) Cluster Masalah Internal dan (ii) Cluster Masalah Eksternal (iii) Cluster Alternatif Solusi. (i) Cluster Masalah Internal adalah penjabaran dari permasalahan atau kendala yang menyebabkan lambatnya perkembangan BMT dari internal BMT itu sendiri. (ii) Cluster Masalah Eksternal adalah penjabaran dari permasalahan atau kendala yang menghambat perkembangan BMT dari luar BMT tersebut. (iii) Cluster Alternatif Solusi adalah penjabaran solusi yang di berikan untuk permasalahan yang telah terjadi.

\section{Masalah Internal}

\section{Kualitas Sumber Daya Manusia}

Permasalahan dalam Sumber Daya Manusia lebih kepada pemahaman terhadap fungsi dari BMT dan pelayanan dalam jasa keuangan syariah. Fungsi Baitul Maal Wa Tamwil ada dua: 1) melakukan pengembangan usaha dan 2) mengumpulkan dana dalam bentuk ZISWAF dan menyalurkannya kepada masyarakat (Aziz, 2008). Fungsi ini sendiri sekarang beralih tidak menjadi dua lagi. Sebagian besar dari BMT hanya berfokus pada orientasi bisnis saja. Padahal dua fungsi tersebut tidak dapat dipisahkan.

\section{Moral Hazard}

Moral hazard atau perilaku jahat dalam ekonomi adalah tindakan pelaku ekonomi yang menimbulkan 
kemudharatan baik untuk diri sendiri maupun orang lain (Hariyanto, 2009). Dalam industri keuangan banyak sekali bentuk-bentuk moral hazard, seperti penggelapan dana nasabah, suap dalam proses financing, pemalsuan laporan keuangan, dan masih banyak yang lainnya. Moral hazard harus sangat diperhatikan dalam industri keuangan karena moral hazard dapat menimbulkan risiko yang cukup berpengaruh terhadap suatu lembaga keuangan. Penggelapan ini terjadi karena lemahnya kontrol dari atasan sehingga terdapat celah untuk melakukan kecurangan. Kasus seperti ini dapat menimbulkan risiko reputasi bagi bank tersebut.

\section{Produk Kurang Inovatif}

Disini yang dimaksud adalah bagaimana inovasi produk dapat berjalan dengan baik. Desainproduk yang dikeluarkan oleh lembaga masih itu- itu saja. Baik dari sisi penghimpunan dana ataupun penyalurannya. Yang seharusnya dapat dikembangkan dan dimodifikasi sehingga lebih menarik dan memenuhi kebutuhan pasar.

\section{Sistem Informasi dan Teknologi yang Kurang Memadai}

Kurang berkembangnya sistem Informasi dan teknologi yang digunakan oleh BMT menjadi salah satu kendala dalam pengembangan BMT itu sendiri. Bagaimana jaringan dan penggunaan teknologi dapat menghasilkan keefisiensian dalam transaksi dan lainnya. Hal ini yang menjadi nilai lebih bagi bank umum yang mengembangkan usahanya pada ranah mikro. Mereka meiliki sistem informasi dan tekologi yanglebih maju.

\section{Masalah Eksternal}

\section{Ketatnya Persaingan Bisnis}

Persaingan bisnis di wilayah perkotaan yang semakin berkembang. Dengan laju perekonomian yang lebih cepat jika dibandingkan dengan pedesaan menjadikan Kota sebagai tempat yang tepat untung mengembangkan bisnis. Khususnya bagi bank umum yang akan mengembang ke ranah mikro makan kota adalah wilayah yang paling awal untuk dijadikan tempat pengembangan bisnis. Dengan berbagai alasan dianatranya lebih menunjang dalam pengunaan teknologi dan sistem yang sudah mereka kembangkan.

BMT sebagai Lembaga Keuangan Mikro akan sangat tertinggal dengan pesaingnya. Hal ini mejadi penyebab sulitnya perkembangan LKM di perkotaan.

\section{Kurangnya Dukungan Pemerintah}

Pemahaman masyarakat terhadapa keuangan syariah yang masih rendah. Dimana sebagian besar masyarakat masih menganggap bahwa keuangan syariah tidak jauh berbeda dengan konvensional.

\section{Kurangnya Pemahaman Masyarakat}

Menurut Arkham dukungan disini adalah terkait sosialisasi kelembagaan, ataupun terkait monitoring Lembaga. Termasuk dukungan hukuman terhadap BMT.

\section{Alternatif Solusi \\ Pengembangan Sistem Informasi dan Teknologi pada BMT}

Pengembangan sitem informasi dan teknologi bagi sebuah perusahaan adalah sebuah kebutuhan mendasar saat ini. Dengan perkembangan zaman saat ini dan semakin mutakhirnya teknologi, menuntut perusahaan untuk menyediakan pelayanan yang efisien dan memudahkan. Dengan memaksimalkan teknologi yang ada. Misalnya dengam webbase untuk semua transaksi yang dilakukan dan penggunaan ATM bagi perbankan yang memudahkan bagi konsumen dan berpeluang meningkatkan keuntungan lebih tinggi dari pesangnya.

Selain dari pada itu, pengembangan sistem informasi dapat digunakan dalam mengiklankan produk baru atau inovasi terbaru dari sebuah perusahaan. Dengan demikin cost marketing dapat ditekan serendah mungkin dengan memaksmalkan sistem informasi dan teknologi yang terbarukan. Yang paling penting saat ini bagi BMT adalah menyediakan Basis Informasi Strategis (Strategic Information Base) yang dapat mendukung daya saing perusahaan.

\section{Pelatihan Bagi SDM}

Pelatihan ini dibutuhkan untuk meningkatkan pemahaman SDM tentang keuangan syariah dan tentang BMT itu sendiri. Hal ini dilakukan untuk meningkatkan pemahaman dan kualitas SDM BMT itu sendiri. Kualitas yang memadai dan pemahaman yang tinggi akan menyebabkan peningkatan pada pelayan keuangan. Sehingga dengan pelayanan yang baik akan menyebabkan anggota merasa puas dan tidak beralih ke lembaga lainnya. Dikarenakan BMT sendiri adalah lembaga dengan status hukum koperasi yang mendahulukan asas kekeluargaan dan mementingkan kebutuhan anggota terlebih dahulu. 


\section{Pendampingan Untuk BMT}

Pendampingan terhadap BMT dari pemerintah (Dinas Koperasi dan UMKM) sangat diutuhkan bagi keberlangsungan BMT itu sendiri. Salah- satu penyebab nonaktifnya beberapa BMT disiyalir akibab kurangnya perhatian pemerintah. Dalam hal ini kurangnya kontroling dan pembinaan yang baik dari pemerintah yang berkaitan. Dengan adanya pendampingan dan kontroling yang baik terhadap BMT akan lebih akan dapat meminimalisir asimetric information dan peluang bangkrutnya lembaga.

\section{Penerapan SOP (Standard Operating Procedure)}

Pembuatan SOP bagi sebuah perusahaan adalah sebuah keharusan. Hal ini digunakan dalam menunjang keberlangsungan kinerja perusahaan. Dan kejelasan deskripsi kerja dari masing-masing bagian dalam perusahaan. Sehingga efektifitas kerja dapat didapatkan. Namun tidak cukup hanya dengan membuat saja, tapi yang paling penting adalah pelaksanaan dari SOP itu sendiri. Hal ini digunakan utuk mebatasi gerak karyawan dan meminimalisir permasalahan Moral Hazard pada sebuah perusahaan.

\section{Penetapan Regulasi Yang Mendukung}

Pemerintah diharapkan dapat membuat kebijakan yang mendukung pertumbuhan usaha mikro secara umum, dan secara khusus Lembaga Keuangan Mikro. Regulasi baik dari tingkat nasional ataupun regional daerah. Sehingga tujuan pengentasan kemiskinan melalui usaha mikro dan keuangan mikro dapat berjalan dengan baik.

\section{Pengembangan produk}

Hal ini berkaitan erat dengan pelatihan yang diberikan kepada SDM. Semikin sering pelatihan yang diberikan akan memungkinkan dapat mengembangkan kreatifitas dan memungkinkan dalam mengembangkan produk BMT. Misalkan dalam pooling fund (pengumpulan dana) dapat dilakukan pengembangan dalam produknya. Baik dalam objeknya yang diperluas tidak hanya kepada individu namun pada perkumpulan (majlis taklim) atau kepada masjid. Atau pada produknya itu sendiri dengan mengadopsi pada akad yang sudah di sahkan oleh Dewan Syariah Nasional.

\section{Sosialisasi Kepada Masyarakat Terkait Keuangan Syariah}

Permasalahan yang dihadapi masyarakat saat ini adalah kurangnya pemahaman terhadap keuangan syariah, maka diperlukan sosialisasi yang masif kepada masyarakat. Agar tidak terjadi gagal paham dari masyarakat atas dasar keuangan syariah. Yang menyebabkan mereka menganggap bahwa apa yang dibawa oleh islam tidaklah berbeda dengan apa yang dibawa oleh kapitalisme.

\section{Kerangka Koseptual}

Dari hasil intervie dan kajian pustaka maka dapat diidentifikasi permasalahan BMT di Kota Bogor, sebagaimana disebutkan diatas. Sehingga dari hasil identifikasi tersebut dapat disimpulkan kerangka konseptual dari penelitian ini sebagaimana gambar 2 .

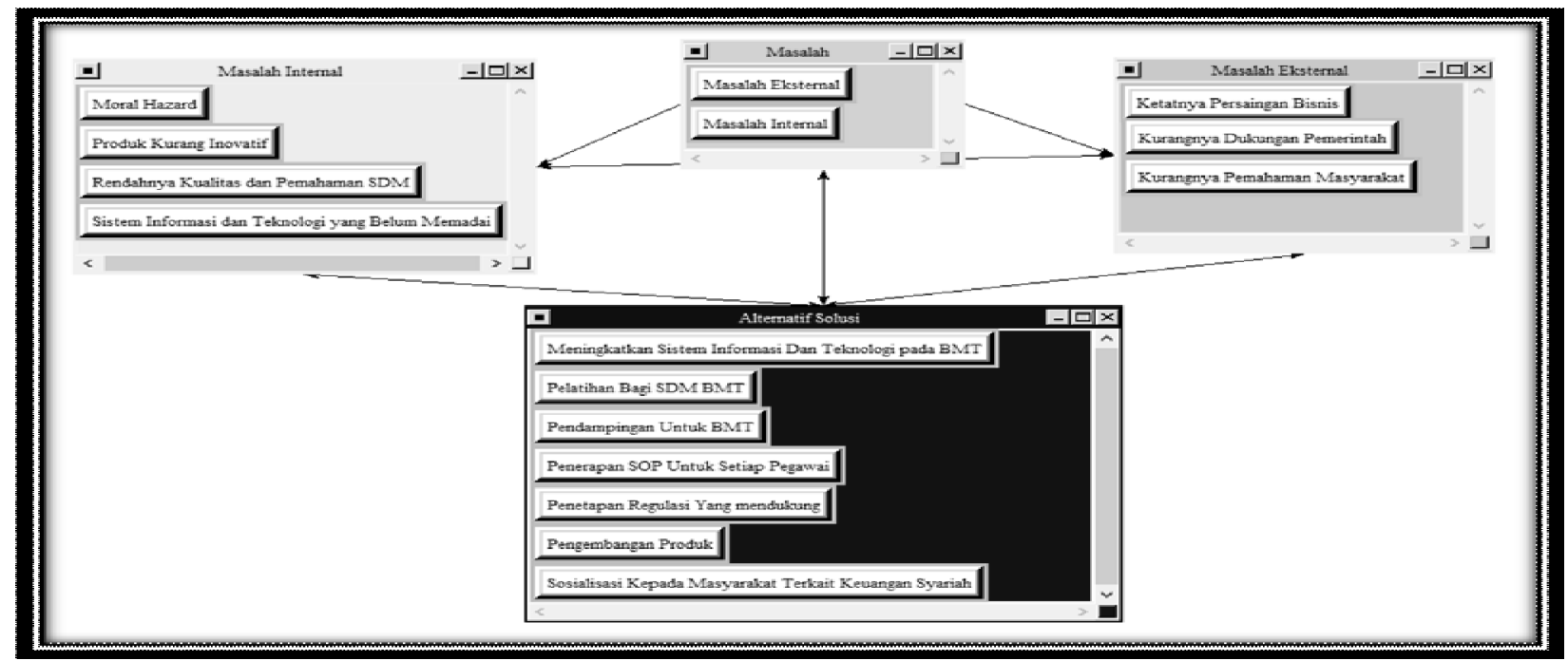

Gambar 2. Dekomposisi Permasalahan BMT di Kota Bogor Data diolah (2015) 


\section{Sintesa dan Hasil}

Hasil di atas adalah hasil wawancara kepada tujuh responden, yang terdiri dari pakar, prkatisi dan akademisi. Dari hasil tersebut diproses dan diolah terlebih dahulu berdasarkan hasil kuesioner masing- masing responden dengan mengacu kepada kerangka jaringan ANP (gambar 3). dari data tersebut dihasilkan dua supermatriks. Diantaranya berupa prioritas permasalahan dan prioritas solusi.

Hasil dari pengolahan tersebut dijadikan satu. Hal ini dilakukan untuk mengetahui tingkat prioritas dari masing- masing aspek menuru para responden. Untuk mencapai hasil tersebut maka nilai pendapat dari masing-masing responden dihitung rata-rata (Geometric Mean) dan nilai kesepakatan (Rater Agreement) dari para responden. Kedua nilai inilah digunakan untuk mnentukan prioritas dari permasalahan dan solusi menurut responden.

\section{Hasil Rater Agreement dan Geometric Mean Permasalahan}

Disini akan menjelaskan bagaimana pandangan dari masing- masing responden terhadapat kedua aspek permasalahan melaluai hasil rater agreement (W). Dimana dalam penelitian ini penulis membagi permasalahan menjadi dua aspek. Yaitu aspek permasalahan internal dan permasalahan eksternal. Sudah dapat dipastikan bahwa sebuah kendala dan permasalahan yang terjadi pada sebuah lembaga tidak akan jauh dari kedua aspek diatas. Aspek internal sebagai inti dalam operasional lembaga dan aspek ekstenal sebagai aspek pendukung dari berjalannya lembaga tersebut.
Dari hasil pengolahan data dapat dihasilkan grafik sebagaimana diatas. Masing- masing responden memiliki pandangan yang berbeda dengan permasalahan ini. Dari grafik di atas responden pertama, ke-5 dan ke-7 menunjukkan hasil yang sama. Dalam artian mereka menyatakan bahwa masalah ekternal sedangkan responden ke-2, ke-4 dan ke-6 menganggap bahwa masalah internal yang menjadi prioritas utama. Serta responden ke-3 yang menganggap bahwa keduanya memiliki tingkat prioritas yang sama.

Namun secara umum pandangan dari pakar menunjukkan bahwa, prioritas permasalahannya adalah masalah internal dengan nilai Geometric Mean $(0,55)$. Untuk prioritas kedua adalah Masalah Eksternal dengan nilai Geometric Mean $(0,45)$ dilihap pada (Grafik: 4.4). Dalam hal ini tingkat kesepakatan (Rater Agreement) dari para pakar atas kedua sapek di atas adalah (W:0,02). Hal ini mendukung pandangan dari Afriadi (2012) yang menjelaskan dalam tulisannya bahwa yang menjadi prioritas dalam permasalahan internal dan eksternal BMT di Indonesia adalah permasalahan Internal. Dimana menurutnya permalahan yang harus menjadi fokus utama adalah penyelesaian dari permasalahan-permasalhan internal. Secara umum antar permasalahan BMT perkotaan dan permasalahan BMT secara umum di Indonesia memiliki fokus yang sama yaitu permasalahan internal.

Hal ini juga disampaikan oleh Hamzah (2013) bahwa fokus prioritas dalam penyelesaian masalaha operasional BMT di Pekanbaru juga menunjukkan hasil yang sama. Yaitu permasalahan internal sebagai prioritas dalam penyelesaiannya. Namun hal ini tidak menujukkan bahwa permasalahan eksternal dapat diabaikan. Dalam beberapa kasus permasalahan

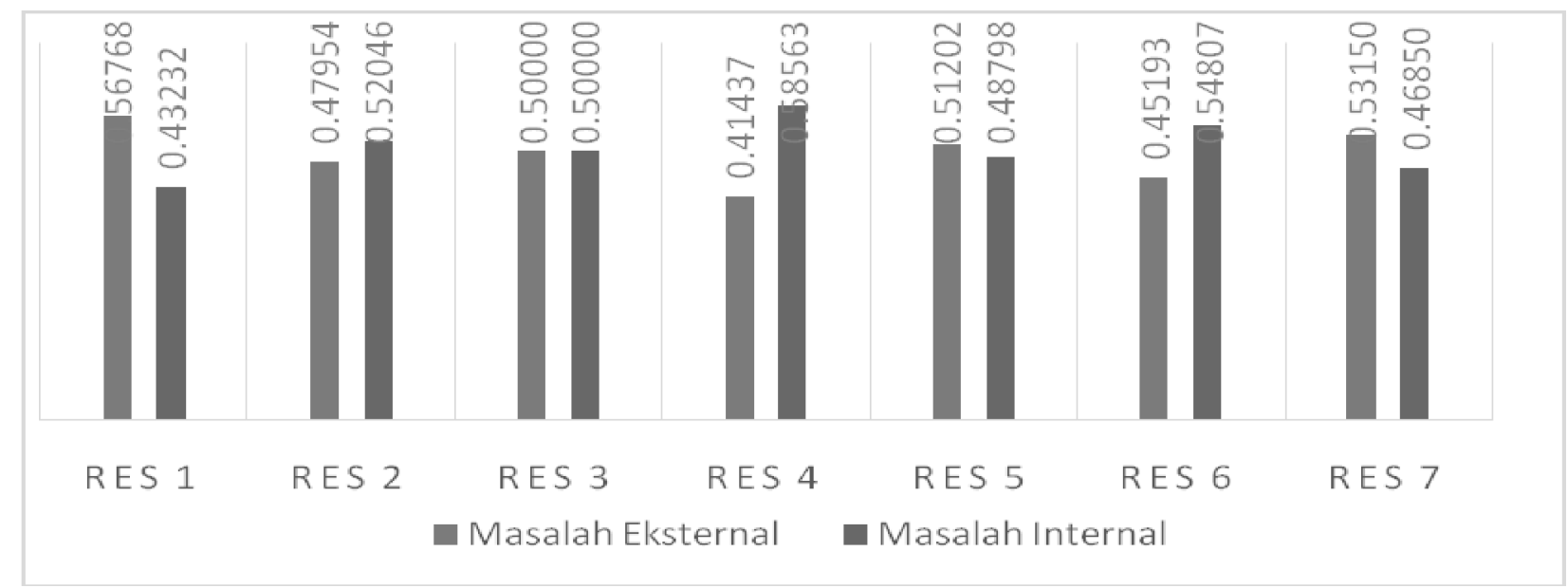

Gambar 3. Grafik Permasalahan BMT Pekotaan (Kota Bogor)

Sumber: data diolah (penulis, 2015) 
eksternal terdapat masalah yang dominan yang juga harus diselesaikan. Seperti permasalahan ketatnya persaingan bisnir dan kurangnya dukungan pemerintah adalah permsalahan yang juga harus segera diselesaikan. masalah menunjukkan masalah internal yang menjadi prioritas.

Apa yang dilihat seolah bertolak belakang, namun keputusan hasil tetap akan menjadikan masalah internal sebagai masalah prioritas. Dengan prioritas

\section{Poll's Result of Masalah}
0.600000
0.500000
0.400000
0.300000
0.200000
0.100000
0.000000

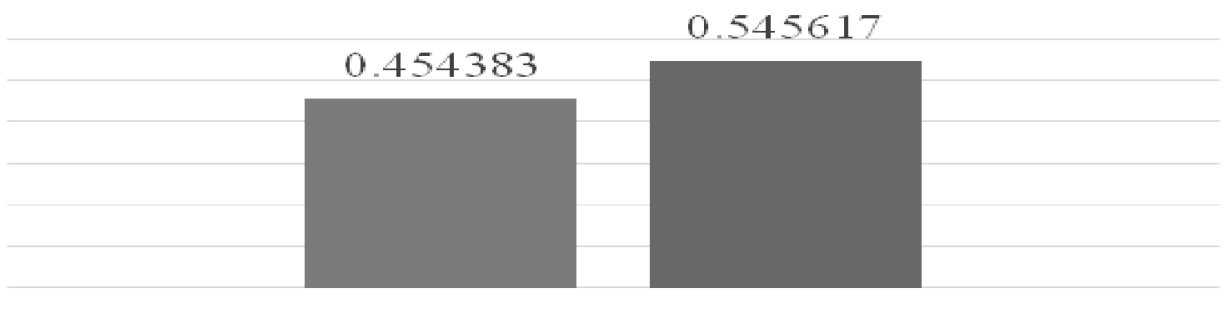

- Masalah Elssternal a Masalah Internal

Gambar 4. Hasil dari Permasalahan dari nilai Geometric Mean

Hasil diolah oleh (penulis,2015)

Hasil Geometric mean Gabungan Masalah

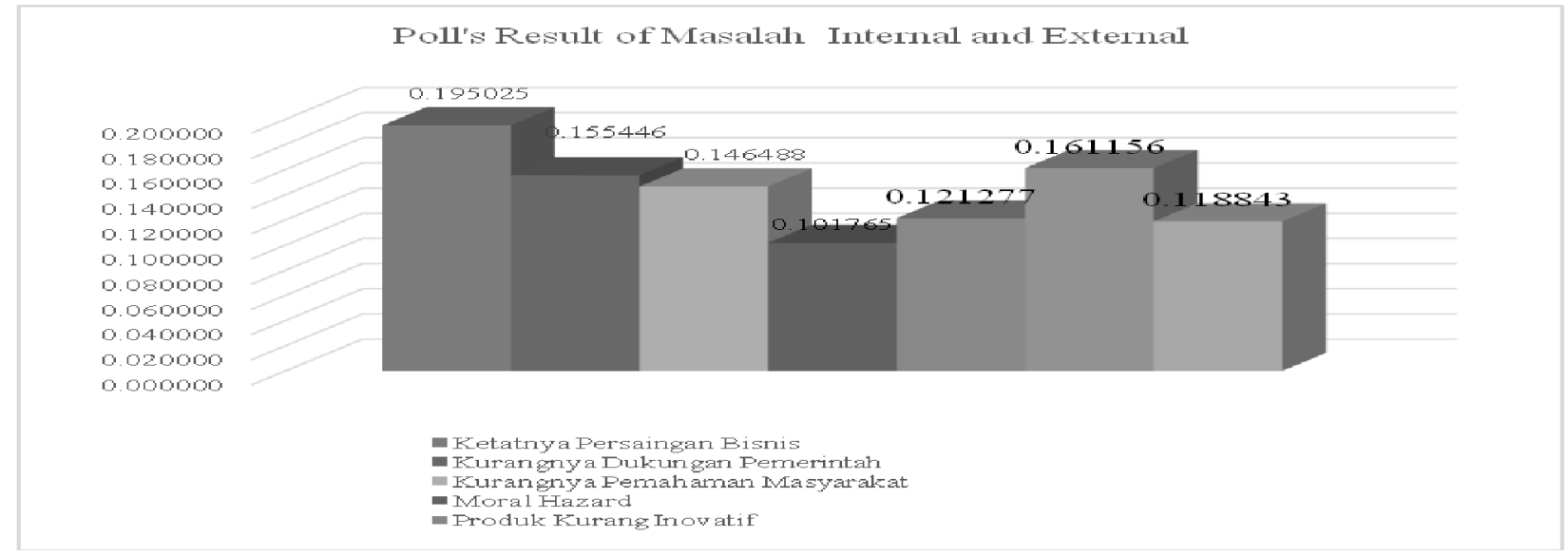

Gambar 5. Geometric Mean gabungan masalah

Data di olah oleh (penulis 2015)

Gambar diatas adalah gambar dari hasil gabungan masalah keseluruhan. Baik masalah internal ataupun eksternal. Dari hasil diatas menunjukkan bahwa masalah yang paling dominan adalah masalah "Ketatnya Persaingan Bisnis" dengan nilai $(0,195)$ dilanjutkan dengan masalah "Rendahnya Kualitas dan Pemahaman SDM" dengan nilai $(0,161)$ baru dilanjutkan dengan masalah "Kurangnya Dukungan Pemerintah" dengan nilai $(0,155)$. Dari urutan prioritas masalah memang menunjukkan bahwa permasalahan dari aspek masalah eksternal yang menajdi prioritas. Namun sebagaimana hasil sebelumnya dari aspek utamanya adalah kurangnya kualitas dan pemahaman SDM. Hal ini dikarenakan masalah yang harus diselesaikan oleh BMT adalah menyelesaikan permasalahan internalnya sebagai pokok utama. Baru dilanjutkan pada masalah eksternal sebagai pendukungnya. Belajar dari analogi Rumah dan Pagar, seseorang tidak akan memperbaiki dan memperindah pagar jika rumahnya sedang mengalami kerusakan. Begitu pula pada BMT penyelesaian awal harus dari internal sebagai inti dari kegiatan operasi dan keberlangsungan dari BMT itu sendiri. Selanjutnya di perbaiki apa yang akan mendukung perkembangan bisnis BMT dari sisi eksternalnya. 


\section{Hasil Rater Agreement dan Geomatric mean Alternatif Solusi}

Pada point ini akan diuraikan hasil dari pegolahan data yang diperoleh dari para responden. Berkenaan dengan alternatif solusi yang dapat diberikan kepada BMT. Dalam upaya mengurangi permasalahanpermasalahan yang ada.

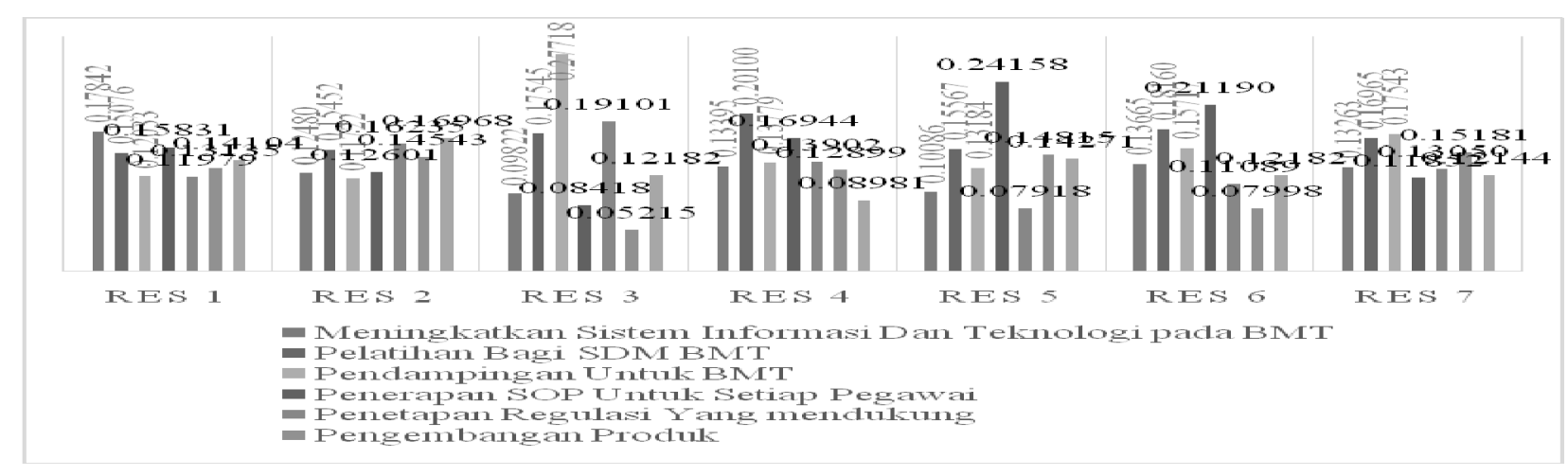

Gambar 6. Alternatif Solusi

Data diolah (2015)

Dari bagan di atas dapat disimpulkan pandangan dari masing- masing responden terhadap aspek "Alternatif Solusi" responden pertama menyatakan bahwa alternatif solusi "Meningkatkan sistem informasi dan teknologi pada BMT" menjadi solusi yang paling dominan yang harus dilakukan oleh BMT di Kota Bogor. Sedang responden kedua menyatakan bahwa solusi "Sosialisasi Kepda Masyarakat Terkait Keuangan Syariah" menjadi solusi yang paling dominan. Dan menjadi prioritas dalam pelaksanaannya bagi BMT.

Sedang untuk responden ketiga dan ketujuh menganggap bahwa solusi "Pendamping Terhadap BMT" menjadi solusi yang paling dominan. Yang berarti mereka menganggap bahwa prioritas pelaksanaan solusi ini harus lebih tinggi dibandingkan dengan solusi lainnya.

Responden keempat menganggap bahwa "Pelatihan Bagi SDM" adalah solusi yang paling dominan. Dengan artian bahwa prioritas pelaksanaan solusi ini harus lebih tinggi dibandingkan dengan solusi lainya. Sedangkan responden kelima dan keenam menggap bahwa solusi "Pembuatan dan Pelaksanaan SOP" menjadi solusi yang paling dominan mernurut mereka. Yang bermakna bahwa prioritas pelaksanaan solusi ini menurut mereka, harus lebih tinggi dibandingkan yang lainnya.

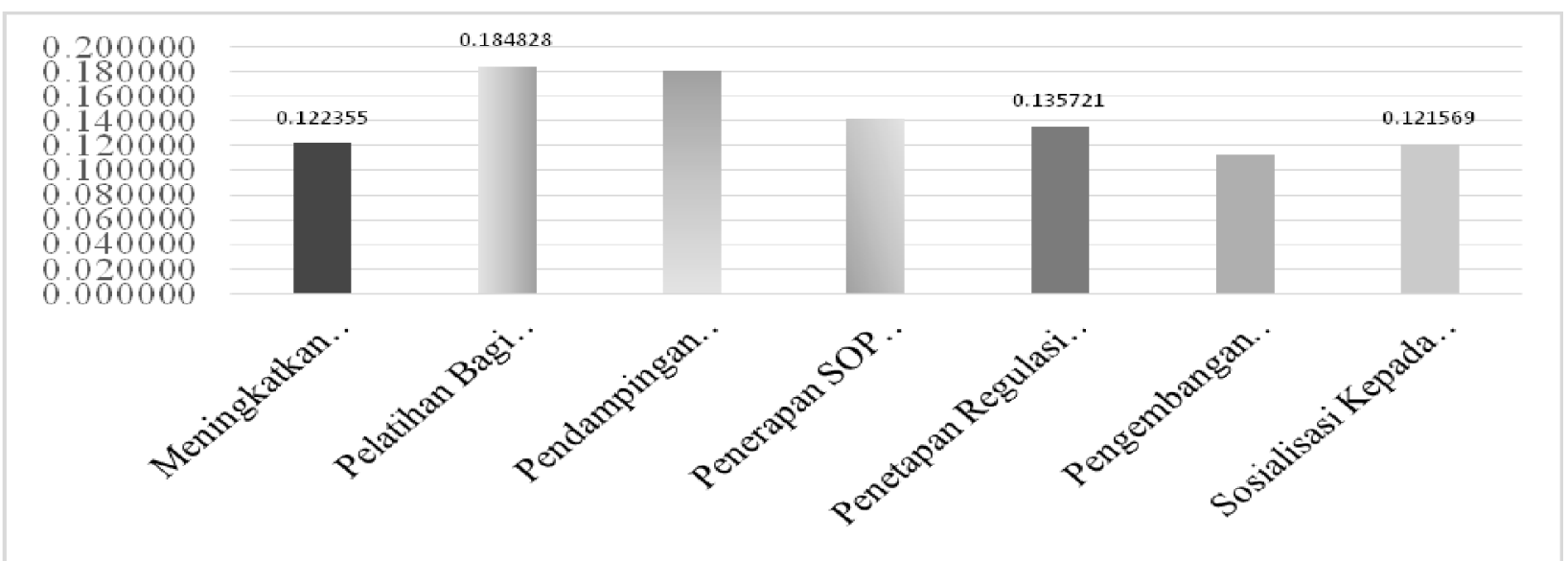

Gambar 7. Hasil Geometrik Mean Aspek Alternatif Solusi

Data diolah oleh (penulis,2015) 
Dari gambar diatas dapat disimpulkan bahwa secara umum responden menganggap Alternatif Solusi 1) Pelatiahan Bagi SDM menjadi solusi yang paling dominan berdasarkan nilai Geomatric Mean $(0,184)$. Hal ini ditujukan untuk meningkatkan pemahaman dan kualitas SDM. Sehingga dapat meningkatkan pelayanan dan berdampak pada tingkat kepuasan anggota. Dilanjutkan dengan solusi 2) Pendampingan Terhadap BMT. Dengan nilai $(0,181)$. Pelaksanaan pendampingan dari pemerintah terkait kepada BMT dalam hal ini monitoring dan perhatian, akan dapat meningkatkan kinerja BMT. Selain itu dapat pula meminimalisir asimatric information dan penyalah gunaan wewenang atas dana oleh para pengurus yang akan menyebabkan bangkrutnya lebaga tersebut. sehingga kejadian yang saat ini terjadi nonaktifnya 9 BMT dari jumlah 14 unit BMT di kota Bogor.

Selanjutanya 3) Pembuatan dan penerapan SOP, menjadi prioritas ke-3 dalam upaya mengurangi permasalahan yang dihadapi pada $\operatorname{BMT}(0,14)$. Selain itu hal ini dapat membuat operasional BMT semakin lebih mudah, dengan diskripsi kerja yang sudah tetap. Serta mengurangi peluang Moral Hazard dengan batasan dan peraturan yang sepakati.

Prioritas selanjutnya yaitu solusi 4) "Penetapan Regulasi yang Mendukung" $(0,136)$. Solusi ini harus menjadi perhatian bagi pemerintah jika menginginkan Usaha Mikro dan Lembaga keuangan Mikro dapat berjalan dengan baik dan menjadi penopang perekonomian negara. Kelima, "Meningkatkan Sistem IT pada BMT", $(0,122)$. Untuk prioritas keenam adalah solusi" Sosialisasi Kepada Masyarakat Terkait Keuangan Syariah" $(0,121)$ dan ketujuh adalah solusi "Pengembangan Produk" $(0,112)$.

\section{KESIMPULAN}

Dari hasil pembahasan di atas dapat diidentifikasi beberapa permasalahan yang terjadi pada BMT Perkotaan khususnya Kota Bogor. Permasalahan ini dibagi menjadi dua bagian. Pertama Masalah Internal dan Masalah Eksternal. Masalah Internal terdiri dari: 1) Permasalahan Moral Hazard, 2) Rendahnya Kualitas dan Pemahaman SDM, 3) Produk Kurang Inovatif dan 4) Sistem IT yang Belum Memadai. Sedangkan Masalah Eksternal terdiri dari: 1) Ketatnya Persaingan Bisnis, 2) Kurangnya Dukungan Pemerintah dan 3) Kurangnya Pemahaman Masyarakat.

Selanjutnya adalah solusi yang ditawarkan oleh narasumber terhadap permasalahan di atas adalah: 1) Meningkatkan Sistem informasi dan Teknologi pada BMT, 2) Pelatihan bagi SDM, 3) Pendamping Terhadap BMT, 4) Pembuatan dan Penerapan SOP, 5) Pengembangan Produk 6) Penetapan Regulasi yang Mendukung dan 7) Sosialisasi Kepada Masyarakat Terkait Keuangan Syariah.

Kesimpulan dari penelitian ini adalah: (1) Berkaitan dengan cluster Masalah, setelah dibagi menjadi dua, yaitu permasalahan internal dan eksternal. Menurut pakar permasalahan yang prioritas adalah Masalah Internal. Hal ini dilihat dari nilai masing masing permasalahan. Masalah Internal dengan nilai $(0,545)$ sedangkan nilai Masalah Eksternal dengan nilai $(0,454)$. Meski demikian tidak berarti bahwa permasalahan dalam Cluster Masalah Eksternal tidak perlu dikhawatirkan. Namun dengan ini prioritas utama dalam penyelesaian masalah adalah pada Masalah Internal. Baru dilanjutkan dengan penyelesaian permasalahan Eksternal. (2) Berkaitan dengan Masalah Internal, menurut pakar masalah yang paling prioritas adalah Rendahnya Kualitas dan Pemahaman $\operatorname{SDM}(0,320)$, dilanjutkan dengan Produk yang Kurang Inovatif $(0,241)$, Sistem IT yang Belum Memadai $(0,236)$, dan Moral Hazard $(0,202)$. (3) Berkaitan dengan Masalah Eksternal. Menurut pakar, prioritas utamanya terletak pada Ketatnya Persaingan Bisnis $(0,392)$, Kurangnya Dukungan Pemerintah $(0,313)$ dan Kurangnya Pemahaman Masyarakat $(0,295)$. (4) Berkaitan dengan aspek Alternatif Solusi. Solusi yang prioritas adalah Pelatihan bagi SDM, dengan nilai $(0,185)$, Pendamping Terhadap BMT dengan nilai $(0,181)$, selanjutnya, Pembuatan dan Penerapan SOP dengan nilai $(0,142)$, Penetapan Regulasi yang Mendukung dengan nilai $(0,136)$, selanjutnya Meningkatkan Sistem informasi dan Teknologi pada BMT dengan nilai $(0,122)$, dilanjutkan dengan solusi Sosialisasi Kepada Masyarakat Terkait Keuangan Syariah dengan nilai $(0,121)$ dan terakhir Pengembangan Produk dengan nilai $(0,112)$.

\section{DAFTAR RUJUKAN}

Al-Qur'an dan terjemah : Syaamil Quran

Abdul Rahman, Abdul Rohim. 2010. Islamic microfinance: anethical alternative to poverty alleviatio. Humanomics Vol. 26 No. 4, 2010 pp. 284-295: Emerald Group Publishing.

Ahmed, H. 2009. Financing Microenterprise: Analytical Study Of Islamic Microfinance Institution. Islamic Economic Studies Vol. 9.

Afriadi, F. 2012. Analisis Permasalahan Internal dan Eksternal BMT di Indonesia Periode tahun 1995- 2011. Skripsi mahasiswa STEI Tazkia. 
Ascarya. 2005. Strategi pengembangan Keuangan Syariah Di Indonesia.

Proceeding seminar internasional Bank Indonesia, Jakarta. Ascarya. 2007. Analitic Network Process (ANP): Pendekatan Baru dalam Penelitian Kualitatif, Pusat Pendidikan dan Studi Kebanksentralan Bank Indonesia. Jakarta. (Working Paper).

Ascarya dan Diana, Y. 2007. The Profile of Micro, Small, and Medium Enterprises in Indonesia and the Strategy to Enhance Islamic Financial Services through BaitulMaalwaTamwiel. Bank Indonesia. (Working Paper).

Aziz, A. 2008. Tata Cara Pendirian BMT. Jakarta: Pkes Publishing (Versi E-Book).

Hamzah, Z.R., dan Zulfadli, H. 2013. Analysis Problem of Baitul Maal Wat Tamwil (BMT) Operation in Pekanbaru Indonesia Using Analytical Network Process (ANP) Approach: International Journal of Academic Research in Business and Social Sciences August 2013, Vol. 3, No. 8.

Harianto, M. Moral Hazard dalam Transaksi Ekonomi: Perspektif Al-Qur an dan Hadis, Media Release 4 Desember, Universitas Muhamadiyah Yogyakarta, Per 06 Oktober 2014 (http://muhsinhar.staff.umy.ac.id/ moral-hazard-dalam-transaksi-ekonomi-perspektif-alquran-dan-hadis/).

Riwajanti, N.I. 2014. Exploring the Role of Islamic Microfinance Institution in Poverty Alleviation Through
Microenterprises Development, A Case Study of Islamic Financial Cooperative (BMT) in Indonesia. Kyoto Bulletin of Islamic Area Studies, 7 (March 2014), pp. 49-66.

Rusdiana, Aam, S., dan Abrista, D. 2012. Mengurai Masalah Dan Solusi Pengembangan Lembaga Keuangan Mikro Syariah di Indonesia: pendekatan BOCRANP: Proceeding IsEF “The $1^{\text {st }}$ Islamic Economic and Financil Research Forum: UIN Sultan Syarif Kasim.

Susanti, S. 2012. Analisis Kendala-Kendalan Pengembangan KBMT di Bogor Dengan Metode: Analytic network Process (Skripsi Mahasiswa STEITazkia).

Saaty, Thomas L dkk. 2006. Decision Making With The Alaytic Network Process. Library of Congress Control Number: 2006924673.

World Bank. 2013. Economic Development and Islamic Finance: edited by Zamir Iqbal and Abbas Mirakhor. International Bank for Reconstuction and Development/ The World Bank 1818 H StreetNW, Washington DC 20433.

Wawancara dengan pak Ali Susanto S.Pt, M,Si. Kasi. Kelembagaan Koperasi Dinas Koperasi dan UMKM Kota Bogor 20 September 15.

Wawancara dengan Bpk. Ir. Andi Ihsan Arkham ketua Tazkia Microfinan Center 9 Oktober 2015

Yaron, dan Benjamin, Mcdonald. 1997. Developing Rural Financial Market. 